Article

\title{
The Role of Religious Leaders in Religious Heritage Tourism Development: The Case of the Church of Jesus Christ of Latter-Day Saints
}

\author{
Daniel H. Olsen $1, * \mathbb{1}$ and Scott C. Esplin ${ }^{2}$ \\ 1 Department of Geography, Brigham Young University, Provo, UT 84602, USA \\ 2 Department of Church History and Doctrine, Brigham Young University, Provo, UT 84602, USA; \\ scott_esplin@byu.edu \\ * Correspondence: dholsen@byu.edu
}

Received: 15 March 2020; Accepted: 13 May 2020; Published: 20 May 2020

check for updates

\begin{abstract}
For centuries, people have traveled to sacred sites for multiple reasons, ranging from the performance of religious rituals to curiosity. As the numbers of visitors to religious heritage sites have increased, so has the integration of religious heritage into tourism supply offerings. There is a growing research agenda focusing on the growth and management of this tourism niche market. However, little research has focused on the role that religious institutions and leadership play in the development of religious heritage tourism. The purpose of this paper is to examine the role of religious leaders and the impacts their decisions have on the development of religious heritage tourism through a consideration of three case studies related to recent decisions made by the leadership of The Church of Jesus Christ of Latter-day Saints.
\end{abstract}

Keywords: tourism development; religious tourism; The Church of Jesus Christ of Latter-day Saints; Nauvoo; Illinois; Salt Lake City; Utah; Temple Square; religious pageants

\section{Introduction}

For millennia, natural and human-built religious sites and landscapes have drawn both the faithful and the curious to travel long distances to participate in or observe religious rituals, or educational and leisure-related activities (Timothy and Olsen 2006; Suntikul and Butler 2018). In recent decades, there has been a dramatic increase in visitation to religious heritage sites by both religious adherents and curious tourists, in part because of the popularization of these sites by government officials, tourism businesses, and entrepreneurs, who market these sites as a part of broader cultural tourism market (Olsen 2003, 2013; Timothy 2011). Religious groups have also historically used their religious sites both for economic benefit and to attract believers and tourists alike in order to fulfill religious goals, including proselytization, pastoral care, hospitality, and outreach (Cohen 1998, 2018; Olsen 2011; Kirillova et al. 2014). In some cases, religious and secular authorities work together to use established religious heritage to fulfill their economic and/or religious goals for mutual benefit (Tilson 2001, 2005).

Even though religious heritage sites may be impacted negatively by increasing numbers of visitors (Shackley 2001; Woodward 2004; Olsen 2006), tourism at religious heritage sites is generally viewed as a positive thing, particularly from an economic perspective. In many instances, religious heritage site managers, tourism officials, tourism businesses, and entrepreneurs view religious heritage as a boon for the tourism industry, taking it on faith that the development of this type of heritage will strongly contribute to economic development (Olsen 2003; Shepherd 2013). At the same time, like other sectors of the tourism industry, the integration of religious heritage tourism sites into larger tourism planning agendas can lead to negative economic, socio-cultural, and environmental consequences, particularly in cases where religious heritage tourism is the main tourism product. 
Many scholars have focused on issues related to religious heritage and tourism development, such as commodification, marketing, and management, as they relate to religious heritage sites and trails (e.g., Shackley 1999, 2001, 2003; Olsen 2003, 2006; Pavicic et al. 2007; Kitiarsa 2008, 2010; Henderson 2011; Eid 2012; Wiltshier and Clarke 2012; Ornella 2013; Haq 2013; Wiltshier and Griffiths 2016; Qurashi 2017; Olsen et al. 2018; Terzidou et al. 2018; Timothy and Olsen 2018). However, very little has been written on how religious leaders influence this type of tourism development, or how "religious groups, organizations, and individuals in different ways use tourism facilities for their purposes," (Stausberg 2011, p. 220), particularly through examining how tourism to their religious heritage sites can help to fulfill religious goals (Cohen 1998, 2018; Singh, 2006; Olsen 2011, 2016). As well, little work has been done on the effects the decisions of religious leaders regarding their religious heritage sites can have on tourism at different scales.

Therefore, the purpose of this paper is to examine the impacts the decisions of religious leaders regarding their religious heritage sites have on the successful development of religious heritage tourism at the local level. This is done through examining three case studies related to recent decisions by leaders of The Church of Jesus Christ of Latter-day Saints regarding their religious heritage, that have, or soon will have, important economic and socio-cultural impacts on tourism development in the cities of Nauvoo, Illinois; Salt Lake City, Utah; and Palmyra, New York. After discussing the role of religion and religious organizations in the development of religious heritage tourism, the authors provide the context for the case studies used in this paper by giving a brief history of the Church and the development of its religious heritage sites. The authors have a combined 30 years of ethnographic and archival research at these sites, and here draw on interviews, participant observation, and secondary source material to then analyze the three case studies. They also use recent interviews with local community leaders and residents in Palmyra and Nauvoo to ascertain their views on the forthcoming changes to their communities (discussed below), as well as archival research that documents developments at these three sites. The authors conclude by discussing how these cases studies can help scholars understand more deeply the importance of religious authorities as key stakeholders in tourism development efforts.

\section{The Role of Religious Leaders and Institutions in the Development of Religious Heritage Tourism}

Religious heritage tourism has long been an important factor in motivating both religious believers and curious tourists to travel to religious sites. In fact, some of the oldest heritage sites in the world are religious in nature. For example, Rountree $(2002,2006)$ highlights several examples of neo-pagan religious sites related to fertility rights and ancient Goddess worship that were the focus of pilgrimage travel (see also Cassar and Munro 2016) and which are still the foci of New Age religious movements (Rountree 2010; Zwissler 2011). In Europe, medieval cities with important national and regional sacred icons or sites exhibited what Preston (1992) called "spiritual magnetism", drawing in pilgrims within national and international catchment areas, leading to fierce competition between these cities. Part of this competition led to the creation of a vast infrastructural and commercial network along popular pilgrimage routes, as well as in pilgrimage destinations themselves, to cater to the needs of pilgrims, including roadways, museums, inns, shrines, chapels, spiritual guides, and votive and souvenir shops (Smiraglia 2013; Sumption 2003; Casson and Casson 2014). Not only has this infrastructure become the base for modern transportation and economic routes and destinations (Coleman and Eade 2018; Timothy and Olsen 2018), but many religious cities continue to act as "commercially profitable religious pilgrimage" centers (Greif 2006, p. 202).

Religious institutions have also influenced human migration and diaspora patterns (Park 1994; Porok 2003), and how people utilize their leisure time (Kelly 1982; Hall 2006). In addition to religious leaders using tourism to further religious goals, such as proselytization, pastoral care, and religious outreach (Sprigg 1980; Cohen 1998; Olsen 2011), religious leaders have also long placed religious prescriptions and proscriptions on their adherents relating to why and where people travel, how they 
should act while traveling, and even how employees in the tourism sector should behave (Cohen 1998; Mattila et al. 2001; Huntley and Barnes-Reid 2003; Olsen 2011, 2016). As well, positive and negative views of tourism from religious leaders can also influence how accepting a community is to tourism and who can access their sacred sites (Olsen 2011).

Religious institutions, like tourism enterprises, also have a long history of commodifying religion for economic purposes. At a basic level, many religious institutions engage in "ritual economies of exchange", where donations are made in exchange for other-worldly promises or blessings (Koskansky 2002). Some religious groups have even created theme parks or tourism-related attractions for economic and religious messaging purposes (see Paine 2019), such as the Holy Land Experience theme park in Orlando, Florida, which replicates the city of Jerusalem as it may have looked during the time of Jesus Christ (Rowan 2004; Branham 2009; Kaylor 2009; Mathews 2015; Crockett and Davis 2016; Chmielewska-Szlajfer 2017; Goh 2017). Other examples include the Anand Sagar theme park in Maharashtra, India (Shinde 2018), the Taman Tamadun Islam theme park in Malaysia (Moal-Ulvoas 2016), the Ark Encounter in Grant County, Kentucky (Bielo 2018), Nazareth Village in Israel (Timothy and Ron 2019), and the now defunct Heritage Village USA in Fort Mill, South Carolina (O'Guinn and Belk 1989). Religious institutions have therefore been critical to the development of the religious heritage tourism supply that is presently being utilized by tourism marketers, business, and entrepreneurs, which supply includes archeological and burial sites, temple complexes, sacred mountains and islands, and even entire cities (Shackley 2001) — many of which are found on the World Heritage List (Shackley 2001; Labadi 2010; Poria et al. 2011; Ballantyne et al. 2016; Olsen and Timothy forthcoming).

Because of this ready supply of religious heritage, tangible and intangible religious heritage has become an important part of domestic and international tourism in the post-World War II era (Lloyd 1998), with several countries attempting to capitalize on their religious heritage for tourism purposes (e.g., Alecu 2010; Metreveli and Timothy 2010; Simone-Charteris and Boyd 2011; Egresi et al. 2012; Carboni et al. 2014; Gedecho 2014; Okonkwo 2015; Kartal et al. 2015; Heydari Chianeh et al. 2018). The importance of religious heritage in tourism development is also suggested in the statement by Bremer (2005, p. 9260) that "tourism and its associated practices [also] interact with religious life and the institutions of religion in virtually every corner of the world." Indeed, according to some scholars, the number of people visiting religious sites ranges anywhere from 300 to 600 million a year (McKelvie 2005; Timothy 2011, p. 387; World Tourism Organization 2011, p. xiii), making religious tourism and pilgrimage travel one of the world's largest tourism niche markets (Timothy and Olsen 2006). Several scholars conclude that the use of religious heritage in tourism development is not surprising, suggesting that pilgrimage and tourism have historically been closely tied together, with religious pilgrimage being the forerunner to modern tourism (MacCannell 1976; Graburn 1989; Cohen 1992). Even today, pilgrimage is viewed as a type of tourism, because regardless of motivation, travel to religious sites generally consists of using modern transportation technologies and tourism infrastructure (Timothy and Olsen 2006). As well, it is at times difficult to overtly distinguish between pilgrims and tourists, during both their travels and the activities in which they participate at sacred sites (Gupta 1999; della Dora 2012).

Due to the importance of religious heritage in the development of tourism in many destinations, religious leaders and institutions are often viewed as important tourism stakeholders. This is especially the case in places where religion is well integrated into cultural ways of life. For example, on the Indonesian island of Bali, efforts to engage in community-based tourism planning include asking religious leaders for their input as a sign of respect and because of the influence of religion on the island (Hawkins and Khan 1998). In Saudi Arabia and Iran, tourism development is run by theocratic-oriented governments, and most of the religious tourism development in these countries is done by government officials (Zamani-Farahani and Henderson 2010; Khaksari et al. 2014). In Israel, the Israeli government encourages Jewish youth to travel to Israel to reinforce their ethnic, patriotic, and religious identities, which efforts require help from Jewish religious authorities (Cohen 2006; Ioannides and Ioannides 
2006; Kelner 2012), while in India, religious leaders and organizations are an important part of the functioning of pilgrimage and religious tourism in pilgrim towns (Shinde 2011, 2012).

While acknowledging that religious institutions are an important stakeholder in the tourism development process, little has been written regarding how religious leaders are integrated into this process, and what kind of decision-making power they have regarding the use of their religious heritage sites for tourism purposes, particularly in post-secular societies. Indeed, in some instances, scholars have argued that because of their lack of tourism training, religious leaders, and managers of religious heritage sites in particular are in need of outside, top-down help and advice (e.g., Stevens 1988; Cameron and Gatewood 2003; Pavicic et al. 2007). While some research has focused on local communities working with religious leaders to improve tourism in specific localities (e.g., Uriely et al. 2003; Terzidou et al. 2008; Di Giovine 2010) and how religious leaders view and react to the negative impacts of tourism development (Millman 1988; Srisang 1989; Olsen 2011), little has been written on broader tourism stakeholder analyses that include religious leaders (Cannizzaro et al. 2017). Considering that religious institutions do not live in a socio-political vacuum (Shackley 2001), and as such engage with external stakeholders regarding the use of their religious heritage for tourism purposes, the influence of religious leaders in the development of their religious heritage sites needs greater attention by tourism and religious scholars.

There are several questions that arise regarding religious leaders and tourism development. For example, what is the role of religious leaders in the development of tourism at religious heritage destinations? How do the views of tourism by religious leaders affect the use and development of their religious heritage sites for tourism purposes (Olsen 2011)? Are decisions regarding the expansion or removal of religious heritage from tourism development made for economic reasons, faith-based reasons, or both? What are the economic, socio-cultural and environmental effects of the decisions of religious leaders on local communities? Are there differences in terms of how religious leaders engage with other tourism stakeholders that are further away from the headquarters or axis mundi of a faith, versus stakeholders located in greater proximity?

The three case studies that follow highlight examples of recent changes made by the leadership of The Church of Jesus Christ of Latter-day Saints to sites or events related to their religious heritage. In each instance, changes to this religious heritage has led, or in the future will lead, to short- and long-term economic and sociocultural issues in the three case study destinations. Before discussing these case studies, however, a brief history of the development of the Church's religious heritage is provided to give a broader religious and historical context for the case studies.

\section{The Development of Latter-Day Saint Religious Heritage Tourism Sites}

The Church of Jesus Christ of Latter-day Saints is a global faith, established in the 19th century and headquartered in Salt Lake City, Utah, in the western United States. A Christian denomination of approximately 16 million adherents with membership in nearly every country of the world, the Church was founded in western New York State in 1830 following a series of visions and divine manifestations reported by its founder, Joseph Smith. ${ }^{1}$ Persecuted for their belief in modern prophets and scriptures in addition to the Bible, Latter-day Saints frequently relocated during the faith's first decades of existence, moving throughout the American Midwest. Eventually, the Church relocated to Illinois, where Smith was killed by a mob in 1844. After his death, most Church members followed a successor, Brigham Young, further west to the Rocky Mountains of North America, where they settled Salt Lake City and surrounding areas in the modern-day states of Utah, Idaho, Arizona, Colorado and Nevada (Arrington and Bitton 1992).

1 Members of The Church of Jesus Christ of Latter-day Saints are sometimes referred to as "Mormons" after the name of one of their books of scripture entitled The Book of Mormon, which, like the Bible, acts as a witness of Jesus Christ. 
According to Tobler and Ellsworth (1992, pp. 595-96), “History plays a vital role in [Latter-day Saint] thought, where it joins with theology and practical religion to answer many of life's questions and to make daily life meaningful, intelligible, and worthwhile .... The foundations of the Church are grounded in a series of historic events, without which the [movement] would be incomprehensible and impotent". However, the development of Church heritage sites is a relatively recent occurrence. The persecution that drove the Church to the Rocky Mountains, coupled with the rigors of pioneering the region, meant that the Church and its followers did little to develop its heritage sites in the 19th century. When the original Church pioneers began to pass away, there was a renewed interested in Church historical sites (Erekson 2005; Olsen 2013), and Church leaders and members began to return to previously abandoned locations during the 20th century and acquire most of its historical sites from individuals and groups who occupied former Latter-day Saint communities.

The development of religious heritage sites coincided with an effort to reshape public perception of the faith. Marginalized and even demonized throughout the 19th century for its theological positions and societal practices, The Church of Jesus Christ of Latter-day Saints came "out from behind its mountain barrier" during the 20th century to "claim a place in America at large" by turning "the American landscape into [its] scrapbook" (Flake 2003, p. 80). Collaborating nationally with the National Park Service, regionally with state and local historical societies, and privately with groups like the Colonial Williamsburg Foundation, the Church sought to use its heritage sites to assert its identity and authoritatively legitimize its history (Esplin 2018; Smith 2006). Following the trend later termed "memorial mania", the faith created visitor sites that could coopt the post-World War II boom in mass tourism (Rugh 2008; Doss 2010). Through these sites, both at their headquarters in the American West but also scattered across the East Coast and the American heartland, the Latter-day Saints inserted themselves into the national narrative, fashioning themselves into what one historian called "super-American" while "creating a new future out of the Mormon past" (Marty 1981, p. xiii; Flake 2003, p. 71).

While Church theology does not formalize pilgrimage in a sacramental way, it informally fosters travel to its religious heritage sites (Jackson 1992; Madsen 2006; Olsen 2006, 2013, 2016; MacKay 2016). Today, the Church annually hosts millions of visitors at sites important to its history. These include memorials and historically restored residences of its founder Joseph Smith and his followers in Vermont, New York, Ohio, Missouri, and Illinois, as well as the headquarters of the faith in Utah (Olsen and Timothy 2018). The Church also has several historical sites along the Mormon Trail, the route along which tens of thousands of Church members traveled when settling in Utah between 1846 and 1869 (Olsen and Hill 2018). Visitors, the vast majority of whom are already members of the faith, make pilgrimages to these sites to "gain greater personal understanding of the history of the Church and its beliefs" (Jackson 1992, p. 592).

In addition to these locations acting as sites of remembrance (Olsen 2013), where church members go "to envision their sacred history within the geography where the events took place" (MacKay 2016, p. 5), Church leaders also use these sites to fulfill religious goals. These goals include witnessing, wherein historical sites act as evidence of "the living God-who-acts-in-history" (Tobler and Ellsworth 1992, p. 596); constructing and maintaining religious identities and faith; promoting positive images of the Church to the general public; and proselytization (Olsen 2013). Olsen (2016) also notes that Church leaders use their religious heritage sites to fulfill the Church's key missions, including proclaiming their message to others, building faith among their current membership, and performing proxy religious ordinances for their deceased ancestors. As such, in conjunction with their religious heritage sites, Church leaders have also produced religious pageants and built temples in close proximity of these sites (Olsen and Timothy 2018). ${ }^{2}$ While these religious heritage sites, pageants, and temples attract millions

2 Temples represent the most sacred religious structures for Latter-day Saints. Members of the faith who meet specified standards of worthiness solemnize their own religious rites there, including marriage for eternity. They also perform religious rites for deceased ancestors, including proxy baptism and marriage ordinances (see Packer 1980). There are more 
of tourists each year (Olsen 2013), bringing positive economic impacts to surrounding communities, several negative impacts, mostly along socio-cultural lines, have also occurred. In addition, as noted in the three case studies below, recent decisions regarding changes to church religious heritage sites, ranging from redevelopment to discontinuance, may further lead to additional impacts for these communities.

\section{Case Studies}

\subsection{Temple Square}

As the world headquarters for The Church of Jesus Christ of Latter-day Saints, Salt Lake City, Utah is internationally synonymous with the Church. While the state tourism board mainly markets Utah's ski resorts and national parks, the largest tourist draw is Temple Square, which is a part of the larger "Church Campus". Temple Square is the location of one of the most sacred buildings in the Church — the Salt Lake Temple (Jackson and Henrie 1983)—with approximately five million people visiting this religious heritage site annually (Olsen 2009). Completed in 1893, the temple is an integral part of Salt Lake City's urban landscape. While the exterior of the Salt Lake Temple is a "must see" attraction for cultural and religious heritage tourists, only church members who have passed a series of worthiness interviews with ecclesiastical authorities can enter the temple to perform sacred rituals and enter into sacred covenants with God (See Figure 1) (Packer 1980; Olsen 2016).

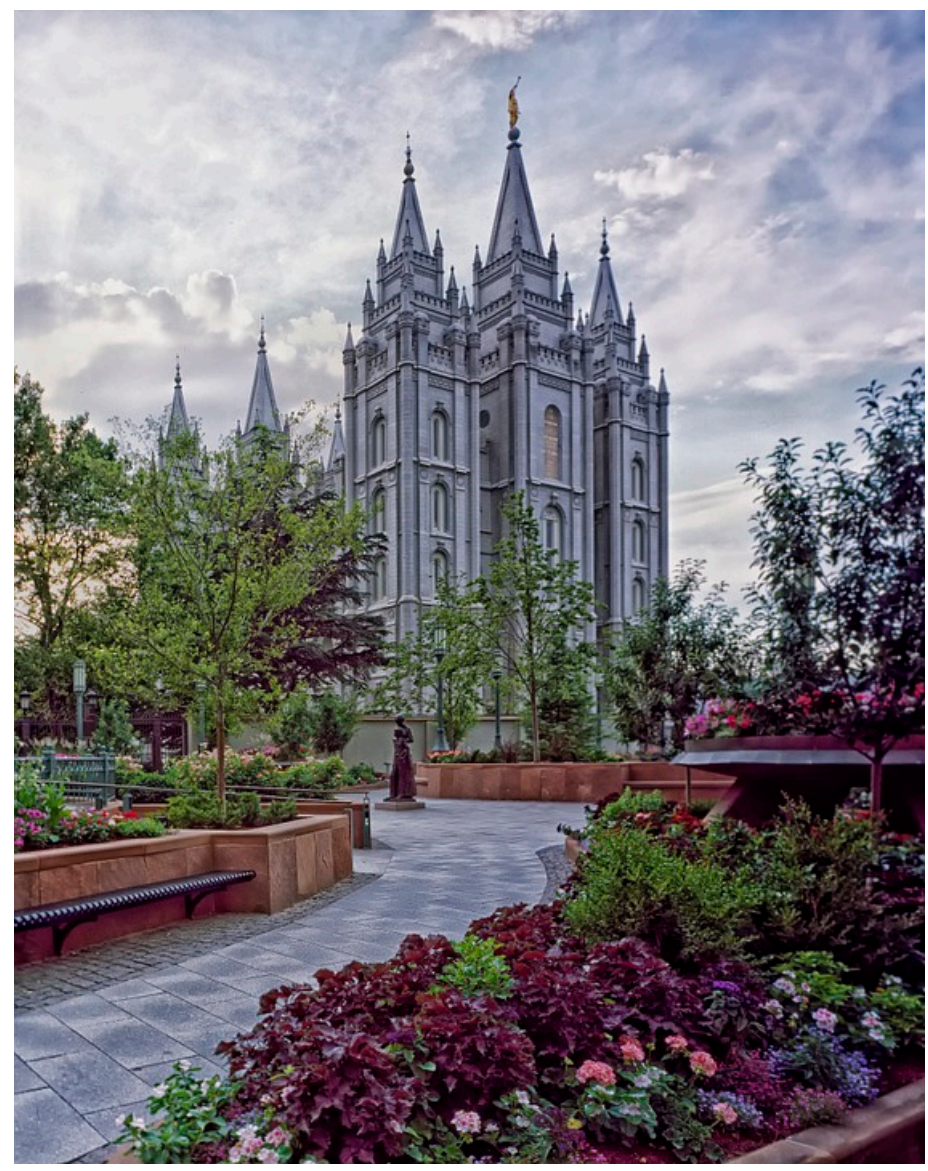

Figure 1. A photograph of the Salt Lake Temple. Source: https://pixabay.com/photos/salt-lake-cityutah-temple-398843/. Used with permission.

than 150 operating temples of the Church worldwide. Among the most iconic are the Salt Lake and Nauvoo temples, as discussed herein. 
While not initially designed for tourists, increasing numbers of visitors to Temple Square have led Church leaders to add several tourism-related buildings on or around Temple Square, including a genealogical center, a museum, and two visitors' centers, among others. In addition, several events are hosted on Temple Square, including public rehearsals by the Tabernacle Choir at Temple Square, organ recitals, and garden tours, among other events (Olsen 2009, 2012, 2019). Church missionaries also lead visitors on tours of Temple Square, where visitors learn about the history of the Church and Temple Square, as well as some of the Church's theological tenets that make it a unique Christian sect (Olsen 2012). The popularity of Temple Square as a tourist attraction has also led Church leaders to create the Temple Square Hospitality Corporation-a for-profit organization that hosts wedding receptions, operates four restaurants, and markets Temple Square to visitors through their website www.templesquare.com (Olsen 2009, 2019; Olsen and Timothy 2018). In addition, from 2003 to 2012, Church leaders invested USD 1.5 billion in the City Creek project to the south of Temple Square, which was comprised of a mix of residential and retail space, including 700 rental properties and 5000 underground parking stalls (Shumway 2015). As such, Temple Square and the Church in general are extremely important to the economic viability of downtown Salt Lake City.

In April 2019, Church leaders announced that the Salt Lake Temple would close for the next four years for renovations (Alton 2019; KSL TV 2019; Pugmire 2019). While the Temple itself would receive an upgrade to its electrical, mechanical, plumbing, and seismic systems, the buildings and exterior grounds around the temple will also undergo several changes, including the removal of portions of the historical wall that surrounds Temple Square, the South Visitors' Center, and the Temple Annex (i.e., church member access to the Salt Lake Temple) to allow for more open viewscapes of the temple to pedestrians and more access points for people to enter Temple Square. Two new buildings or visitor pavilions will replace the South Visitors' Center, and a new Temple Annex will be built on the north side of the temple (Alton 2019; Pugmire 2019). The award-winning landscaping of Temple Square will also be refreshed with a greater emphasis on visitor experience, and will include new flowerbeds, fountains, and upgrades to pedestrian walkways through Temple Square. The pedestrian plaza between Temple Square and church buildings to the east of Temple Square will also be changed to make it more public-friendly, and will include "new thematic elements and aspects of the life of Jesus Christ" (KSL TV 2019). In addition, the interpretational focus of guides at Temple Square will place a greater emphasis on "the life, ministry, and mission of Jesus Christ in His desire to bless every nation, kindred, tongue, and people" (Alton 2019; see KSL TV 2019; Pugmire 2019; Walch 2019). Because of all the changes that would be taking place to Temple Square, church leaders posted a virtual walk-through of the renovations to the temple grounds on YouTube to help people visualize what these changes might look like at the end of the construction period. ${ }^{3}$

While this reconstruction project will cause several short-term issues, including greater traffic congestion due to the temporary closures of sidewalks and roads around Temple Square and noise from the construction (Nielsen 2019), Church leaders have promised to coordinate with city leaders to minimize these issues. In terms of the operationalization of tourism on Temple Square, most buildings, including the North Visitors' Center, will be open to the public. Also, tours offered by Church missionaries will continue (albeit in modified form) (Alton 2019), and most events on Temple Square, including public rehearsals, organ recitals, and the famous Christmas lights on Temple Square, will also continue to be offered. While the construction on Temple Square may impact tourist visitation rates and thereby the local economy in the short-term, local and state governmental officials are supportive of the project. The state Governor, Gary Herbert, has theorized that the temple construction will bring visitors to Temple Square out of "natural curiosity". Governor Herbert has also suggested that this construction project is a part of the overall growth and vitality of Salt Lake City as a whole, and that the state will benefit from the construction project over the long-term (Nielsen 2019). For example, when

3 The YouTube video can be found at https://www.youtube.com/watch?v=hC3RRp3vCMU. 
the construction of the Salt Lake Temple is complete in 2024, it is expected that well over 750,000 people from around the world will attend the temple's public open house (Walch 2019), and some community leaders have also suggested that the Temple Square reconstruction will not just boost tourism in the long-term, but may also help with the city's bid to host the 2030 Winter Olympic Games (Pugmire 2019).

\subsection{Nauvoo, Illinois}

From 1839 to 1846, Nauvoo, Illinois served as the headquarters of The Church of Jesus Christ of Latter-day Saints. A prosperous but turbulent era in the faith's history, Nauvoo experienced an economic boom as thousands of converts relocated from across the United States and Great Britain, causing the city to rival Chicago as one of the largest communities in Illinois (Bennett et al. 2010, p. 127; Klein 1979, p. 1). Disturbed by growing Latter-day Saint economic and political power, as well as its controversial theology, neighboring communities grew weary and wary of the faith and its members. Eventually, as had occurred in earlier Latter-day Saint communities, mob violence engulfed the city. Church president Joseph Smith was killed, and thousands of members were forced to evacuate, abandoning homes, businesses, and a stately temple only recently completed. Learning of the vacant structures and abandoned farms, other settlers slowly reoccupied a town that quickly went from boom to bust. The temple, a visual symbol of the faith, was torched by an arsonist, then leveled by a tornado, and Nauvoo became a nondescript rural farming community on a bend in the Mississippi River in western Illinois (Leonard 2002).

Throughout the mid-20th century, Latter-day Saints slowly became interested in reacquiring property in their former city. First, private individuals, and later the Church itself, acquired dozens of historic sites, until they eventually owned nearly half of the city. Patterning the project after the restored American history site of Colonial Williamsburg (Davis and Austin 2002; Pykles 2010; Esplin 2018), and to a lesser extent New Salem, the home of Abraham Lincoln (Bruner 1994; Cluff et al. 2018), the Church renovated and rebuilt homes and businesses, and stationed interpretive guides dressed in period costumes to transport visitors back in time to the Nauvoo of the 1840s. As the membership of the faith has grown, so have the number of visitors to Nauvoo, and annually, hundreds of thousands of religious tourists descend on this town of approximately 1000 residents (Olsen and Timothy 2002; Esplin 2018).

This religious heritage project was initially met with enthusiasm from the community, who were excited about the economic benefits and notoriety that religious tourism might bring to their city. Local newspapers tracked the presence of "noted visitors", including high-ranking church officials, businessmen like hotel magnate J. Willard Marriott, and National Park Service director Conrad Wirth, who came to explore the possibility of restoring historic Nauvoo (Nauvoo Restoration 1962). Partnerships were formed with senior officials from the Colonial Williamsburg Foundation, lending historical credibility to the project (Esplin 2018). Reflecting greater interest in the economic rather than the religious potential for the project, rumors circulated among residents of motels, restaurants, a shopping center, and a golf course that would accompany any development, together with vacation activities such as boating, horseback riding, and hiking (King 1970b; Hamilton 1966). While one commentator urged caution that "unfounded rumors and surmises have stimulated some active imaginations unreasonably," it was difficult to rein in the speculation generated by the growth in religious tourism (City Cooperation to a Necessity 1962). A local newspaper editor crowed, "restoration is the salvation of Nauvoo ... . The Mormons will be a good influence here" (Rebuilding at Nauvoo 1970, p. 6).

As the project took shape throughout the latter half of the 20th century, a gap emerged between local expectations and restoration reality. Predominantly Latter-day Saint visitors came by the hundreds of thousands to tour restored homes and regale in tales of their religious past, but the amenities hoped for by residents failed to materialize. While some business owners benefited from the boom, others doubted the intentions of the Church for the project. One travel writer concluded, "Concern by Nauvoo residents of Mormon economic and political control in the area is really what lies in back 
of any remaining friction between the old and new neighbors" (Dennis 1975, p. 17). One of those neighbors, the president of the local chamber of commerce in the 1970s, remarked, "We are not a part of the big plan .... They told the people what a wonderful thing they were doing for Nauvoo. But with all this building and with all the publicity, we can't interest businesses in moving here," reflecting a consequence of the project's "tight hold on future developments" (Rebuilding at Nauvoo 1970, p. 6).

In addition to expressing concern about being left out of economic planning or even benefit, some residents bristled at the prominence of the Latter-day Saint story over other histories. One remarked, "We are well aware of Nauvoo's role in the history of the Mormons. But after they left, Nauvoo had an interesting history of its own ... and we have managed to maintain a modest prosperity here since the Utah Mormons left" (King 1970a, p. 55). A national writer familiar with the project more emphatically questioned, "Could the community keep its identity in the wake of the saintly steam roller?" (Rebuilding at Nauvoo 1970, p. 6).

As Nauvoo moved into the 21st century, the impacts of religious tourism continued to be felt in this rural western Illinois town, especially through one of the faith's highest profile historic projects. In 2002, the Church completed the reconstruction of the Nauvoo Temple-a 54,000 square foot, five-story building, soaring 165 feet above the town. Built at an estimated cost of USD 30 million, the building served as the crown jewel of the Church's restoration project, and it was expected that the complete temple would help to attract as many as one million visitors each year in the most optimistic projections (Martin 2000b; Moore 2002).

The temple project polarized Nauvoo residents. With the projected influx of visitors, some residents, particularly those who ran tourism-related businesses, were excited about the temple development project. As one city councilor remarked, "I think it's been pretty good. It's made all of our property worth more .... It's beautiful. They sure made my house look a lot better. It's really for the better of the town. I see nothing bad about it" (Dahl and Norton 2003, p. 36). Another longtime resident summarized, "My theory on the Mormon temple is anything for the betterment of the town. I think it will be a good thing for the town, although a lot of people complain" (Dahl and Norton 2003, p. 339). Other residents, however, grumbled that their way of life would forever be changed. "The city is split right now," remarked a city councilor during the temple's construction. "There's a handful of people that are against any kind of growth. Those are the ones you hear, the loudest ones. They're not really anti-Mormon as much as they don't want to change their way of life" (Dahl and Norton 2003, p. 156). He continued, "We felt, hey you're going to take away our quiet little town" (Van Biema and Grace 2000, p. 64). The town's newspaper owner echoed the sentiment, "They want to take back Nauvoo, and since they can't do it with guns, they are doing it with money" (Van Biema and Grace 2000, p. 65). Chamber of commerce president Steve Sanders took a middle ground approach: "Some people are not happy with what is happening. I have heard the word cult. But as a businessman, it's the best thing that ever happened to me" (Cawthon 2000, p. A1). He continued, "It's the hand the community has been dealt. The county needs it. Hancock County needs an economic boost. This is what has been offered to us" (Martin 2000a, p. D10).

One of the immediate issues that arose in Nauvoo with the rebuilding of the temple was that, with few zoning laws in place to control construction of such an impactful building, city officials were left scrambling to compensate for the impact of projected incoming religious tourists on its town infrastructure, including roads and sewers, as well as public safety officers like police and fire officials. Negotiations led to the Church contributing more than USD 400,000 towards these expenses, causing the local newspaper editor to quip, "We're proud of the council for getting some money out of it" (Van Biema and Grace 2000, p. 65; Martin 1999). In addition to improving public utilities and constructing a community parking structure, the money was used to purchase a bigger fire truck and enlarge the existing fire station, both necessary due to the size of the temple (Martin 2001).

However, over a decade after the rebuilding of the Nauvoo Temple, and several decades since large numbers of pilgrims began descending upon the city, hindsight reveals the impact of religious tourism in Nauvoo. Interviews between the authors and residents reveal that underlying divisions 
linger. While an estimated one million people visit Nauvoo every year, bringing financial benefits to the area, tax assessments have increased, as outside investors or retired couples transform family homes into vacation rentals and second residences (Van Biema and Grace 2000, p. 65). Additionally, this land/home speculation, coupled with a downturn in the economy in 2008 and the realities of seasonal tourism, has led to a landscape with unfinished hotels and shuttered grocery stores and gas stations. Even the local elementary school was forced to sell their decaying building and consolidate with the junior high school due to changing demographics (Gertz and Gertz 2014; Nauvoo Community Center Project History 2019). This change was facilitated in part by traditional family homes being converted to tourism properties and escalating home values pricing out some local residents (Kinzer 2004).

\subsection{Church Pageants}

While religious pageants, plays, and dramas have generally been identified as a medieval European phenomenon (Parker 1935), these types of performances became popular in the United States in the late 19th century and peaked in popularity during the first third of the 20th century (Bushman 2009). Religious passion plays in particular are still popular throughout the United States, including The American Passion Play (1924) in Bloomington, Illinois; the Zion Passion Play (1935) in Zion, Illinois; The Black Hills Passion Play (1939) in Spearfish, South Dakota; The Great Passion Play (1968) in Eureka Springs, Arkansas; and The Promise (1989) in Glen Rose, Texas, among others (Monk 1998). These pageants and plays were designed to "personify ... norms and values specific to a particular community's world view [ $\ldots$ and] promote and inculcate values, ideas, and aspirations of social, religious, and political orders through the instrumentality of spectacle and dramatic engagement" (du Toit 2009, p. xiii).

It was during the time of heightened interest in religious performances in the United States that the Church began to sponsor several religious pageants to promote religious solidarity, celebrate faith among church members, proselytize, and to engage in public relations efforts (Bell 2013; Hunter 2013; Olsen 2013; Jones 2018). As a form of "ritualized theater" (Bell 2013, p. 163), these pageants, which are generally held outdoors near sites of historical importance in Church history, tell the stories of the early beginnings of the Church, and celebrate its early pioneer ancestry, its restored scripture, and the life of Jesus Christ (Olsen and Timothy 2018; See Table 1). While early Church pageants were local productions, with local Church leaders and members spearheading the writing and development of these pageants, more recently greater Church sponsorship has led to these pageants becoming high-tech spectacles, complete with lighting, elaborate costumes, temporary staging, and special effects (Bell 2013; Hunter 2013). The Hill Cumorah Pageant in upstate New York in particular has received attention in the national media because of the large numbers of attendees to this pageant (Applebome 2011).

On 27 October 2018, Church leadership announced that they were scaling back their large religious pageant productions. In a press release, Church leaders stated:

The Church of Jesus Christ of Latter-day Saints is growing across the earth. As this occurs, local Church leaders and members are encouraged to focus on gospel learning in their homes and to participate in Sabbath worship and the Church's supporting programs for children, youth, individuals and families. The goal of every activity in the Church should be to increase faith in the Lord Jesus Christ and to share His gospel message throughout the world. Local celebrations of culture and history may be appropriate. Larger productions, such as pageants, are discouraged. (West 2018)

In a modified press release dated 2 December, 2018, Church leaders clarified that they had previously approached local Church and community leaders as a part of the process of deciding which pageants would be discontinued (Church Newsroom 2018). According to the public affairs director of the Hill Cumorah Pageant, "Leaders [of the Hill Cumorah Pageant] said they took under consideration how to reduce the burden of church member time commitments, cost, security, impact to church sites and more in their decision" (Lonsberry 2018). Megan Sanborn Jones, a Latter-day Saint scholar, 
hypothesized that the discontinuance of Church pageants may be part of the Church's larger "revision of the relationship between public and private worship"-where Church leaders are emphasizing a "new home- and family-centered, church-supported model of gospel engagement" (Turner 2018). In addition, since some Church pageants have seen declining attendance in recent years (Saal 2019), it is possible that Church leadership wishes to invest their resources in other areas of Church growth and proselytization work.

Table 1. A list of Church pageants prior to the discontinuance announcement (Olsen and Timothy 2018; Weaver and Roe 2018).

\begin{tabular}{|c|c|c|c|}
\hline Name & Location & Description & Status \\
\hline Nauvoo Pageant & Nauvoo, Illinois & $\begin{array}{l}\text { This pageant highlights the } \\
\text { building of the City of Nauvoo and } \\
\text { the Nauvoo Temple by early } \\
\text { Church members }\end{array}$ & $\begin{array}{l}\text { Continuing, alternating } \\
\text { nightly with the British } \\
\text { Pageant }\end{array}$ \\
\hline $\begin{array}{l}\text { Mesa Easter Pageant: } \\
\text { Jesus the Christ }\end{array}$ & Mesa, Arizona & $\begin{array}{l}\text { This passion play tells the story of } \\
\text { the life and ministry of Jesus Christ }\end{array}$ & Continuing \\
\hline British Pageant & $\begin{array}{l}\text { Chorley, Lancashire, UK, } \\
\text { and Nauvoo, Illinois }\end{array}$ & $\begin{array}{l}\text { A commemoration of the history of } \\
\text { the Church in the British Isles }\end{array}$ & $\begin{array}{l}\text { Continuing every four } \\
\text { years in England and } \\
\text { annually in Illinois } \\
\text { (alternating nightly with } \\
\text { the Nauvoo Pageant) }\end{array}$ \\
\hline $\begin{array}{l}\text { The Hill Cumorah } \\
\text { Pageant }\end{array}$ & Palmyra, New York & $\begin{array}{l}\text { Depicts the storyline of The Book of } \\
\text { Mormon and recounts the founding } \\
\text { of the Church }\end{array}$ & $\begin{array}{l}\text { Discontinued after } 2021 \\
\text { run }^{1}\end{array}$ \\
\hline $\begin{array}{l}\text { The Mormon Miracle } \\
\text { Pageant }\end{array}$ & Manti, Utah & $\begin{array}{l}\text { A pageant depicting } \\
\text { faith-promoting stories of early } \\
\text { Church members }\end{array}$ & $\begin{array}{l}\text { Discontinued after } 2019 \\
\text { run }\end{array}$ \\
\hline Castle Valley Pageant & Castle Dale, Utah & $\begin{array}{l}\text { This pageant highlights the history } \\
\text { of Church pioneers in the region }\end{array}$ & $\begin{array}{l}\text { Discontinued } \\
\text { immediately }\end{array}$ \\
\hline Clarkston Pageant & Clarkston, Utah & $\begin{array}{l}\text { Recounts the life of Martin Harris, } \\
\text { an important figure in Church } \\
\text { history, who lived in Clarkston in } \\
\text { the latter stages of his life }\end{array}$ & $\begin{array}{l}\text { Discontinued } \\
\text { immediately }\end{array}$ \\
\hline
\end{tabular}

\footnotetext{
${ }^{1}$ The final Hill Cumorah Pageant performance was to be 2020, but because of the COVID-19 pandemic the final
} performance was pushed back to 2021.

While the decision to discontinue these pageants is expected to increase crowd size at the final Hill Cumorah Pageant in 2021 (Walch 2018), in some ways it comes as a relief for those involved in the year-round planning and execution of the pageants at the local level, who will get their "summers back" (Stack 2018a; Saal 2019; Toone 2019). However, as highlighted in several news articles, many government officials, local non-profit organizations, and local church members and residents in Manti, Utah and Palmyra, New York have expressed concerns regarding the social ramifications of the discontinuation of their pageants. In particular, many feel that the loss of these pageants will affect community pride and cohesiveness. For example, one Manti resident suggested that the discontinuance of the Manti Pageant would lead to a loss of community, where locals "won't unite in a common goal the way they have for 52 summers" (Saal 2019). Another resident lamented the loss of the pageant, noting that the "pageant has been an essential part of community life in Manti, especially for the city's young people who participated" (Stack 2018a). In the case of the Hill Cumorah Pageant, the Mayor of Palmyra lamented: "I think anytime you lose something of that magnitude, it's a loss to your community .... I'm really sorry it's going to be gone. It's something that I've grown to know that was going to be here every single year of my lifetime so I think it's probably going to be missed" (Bundt 2018). At the same time, for some Manti residents, there is a sense of acceptance regarding the end-run of the pageants. As one Manti resident stated, "There's a part of relief that hey, maybe we're going to take a family vacation. There's sadness, but there's also acceptance, like that was a good 
run.... A lot of people have invested lifetimes, but it was something meaningful, so we can let it go" (Toone 2019).

The discontinuance of the pageants also will have a negative economic impact. As Stack (2018a) notes, there were over 75,000 visitors for the 2018 performances of the Manti Mormon Miracle Pageant. The loss of these visitors will surely affect Manti's motels, hotels, and restaurants which are in some cases dependent on the income from the pageant attendees for economic self-sufficiency. In the case of the Hill Cumorah Pageant, one Palmyra business owner noted: "We thrive off of the tourists coming into town .... It's not just Mormons that come in; it's outsiders too coming in to see what they're all about. We thrive off of anything that brings publicity to this little community here." Another resident stated: "I've heard [of] people just coming here for the pageant, so it's absolutely going to hurt this community ... . I'm sure it's going to have some effect on Rochester as well." Local community leaders seemed to downplay the economic effects of the cancelations of the pageants to news reporters (Bundt 2018; Stack 2018a), in part because of year-round religious tourism. However, for many local rotary and community clubs in Manti and Palmyra, the pageants represent their biggest fundraiser of the year, and as such will necessitate a need to search for other fundraising opportunities (Stack 2018b; Walch 2018; Riess 2019).

\section{Discussion}

In each of the above case studies, the religious heritage of The Church of Jesus Christ of Latter-day Saints has become an important part of the economic prosperity and socio-cultural identities of residents in Salt Lake City, Utah, Nauvoo, Illinois, and in the locations where church pageants have a long history. However, decisions by Church leaders regarding their religious heritage have had mixed short- and long-term impacts on these local communities. As such, each case study illustrates different ways in which religious leaders can have either a positive or negative influence on tourism development at the local level.

The case of Temple Square demonstrates the impact that religious investment and redevelopment can have on the local tourism industry. Temple Square is synonymous with The Church of Jesus Christ of Latter-day Saints, with the site itself being the major tourist attraction in Salt Lake City in terms of overall visitation numbers. In addition, Temple Square and its religious surroundings are purposefully utilized by Church leaders as both a missionary tool and to bolster faith among its membership. As arguably the most important holy site in the Church, Temple Square needs to be consistently maintained and beautified (Olsen 2009, 2012; Olsen and Timothy 2018). While the four year renovation of the Salt Lake Temple and its surrounding environment is expected to cause traffic delays and noise and will affect the interpretational efforts of Temple Square tour guides, visitor experiences at Temple Square, and tourism receipts in general, these short-term negative impacts are viewed by Church leaders and community leaders as a necessary part of the future growth of the city's tourism industry. Indeed, this multimillion-dollar investment to reconfigure Temple Square to better meet the religious goals of the Church is expected to enhance the tourism industry in the future. In addition to expected record crowds from around the world to visit the newly renovated Salt Lake Temple, this enhanced religious heritage attraction is also expected to enhance efforts by local and state officials in their bid to host a future Olympic Games, as well as to increase overall tourism numbers to both Temple Square and Salt Lake City more broadly. ${ }^{4}$ Because of this, local and state government and tourism officials strongly support the renovations and changes to Temple Square, and are willing to deal with potential short-term loss in tourist numbers and revenue for perceived long-term benefits. As such, this case study highlights the importance of informal church/state partnerships in the development of religious heritage tourism, wherein symbiotic relations help both parties to benefit from tourism development.

4 Salt Lake City hosted the 2002 Winter Olympic games, which games were deemed successful from an economic, tourism, and, from the church's viewpoint, public relations perspective (see Gerlach 2002; Lunt 2007). 
The Nauvoo case study demonstrates the impact of religious heritage site expansion and redefinition on small communities, especially when an outside religious minority headquartered hundreds of miles away has a disproportionate influence on economic and tourism development. As noted above, Church and community leaders have not always agreed on how religious heritage tourism development should progress, a reality that has divided this quiet community. As former Nauvoo mayor Dale Bruegger once commented: "It's our town, as far as we're concerned .... And as far as the Mormons are concerned, it's their town." (Egan 2000, p. A8). While Church leaders have tried to portray Nauvoo as a community frozen in time-a perception perpetuated by period homes and costumed actors (Davis and Austin 2002; Olsen and Timothy 2002)-for the residents of Nauvoo, "Nauvoo is not so much a tombstone to a dead past as a monument to a living present" (Klein 1979, p. 7H). Even though some of Nauvoo's residents have benefited economically from the Church's development of the town as a religious tourism destination, with Church leaders having given money to the town government to improve its infrastructure to handle the pressure on the town's resources (KHQA Newsdesk 2013), some residents have become antagonistic against future religious tourism development. This is particularly the case with quality of life issues and increasing land speculation, which has accompanied this religious heritage tourism development. At issue, therefore, is "whose" Nauvoo gets to be developed, represented, and interpreted to visitors, and whether the small town feel of Nauvoo can be retained in the face of increasing tourism pressures.

In the last case study, the decision by Church leaders to end Church pageants has, in essence, created winners and losers. As noted above, some community members cheered this pronouncement, being relieved their pageants would not continue, while others lamented the loss of these pageants, noting both the loss of revenue and socio-cultural identity in these communities. While acknowledging the negative economic and socio-cultural impacts that ending these pageants will have within these communities, Church leaders, as custodians of their religious heritage, are acting in what they feel are the best interests of the Church and its members-in this case, divesting this part of their religious heritage.

What has led Church leaders to (re)invest in some religious heritage sites and divest the Church of other aspects of its religious heritage? At the core of these decisions to develop, redevelop, or discontinue certain aspects of religious heritage is a broader move by Church leaders to make their religious heritage sites more religious. This seems to run counter to arguments made by several scholars and theologians who suggest that religious site interpretation should be (re)conceptualized to meet the challenges of a post-modern, post-secularist world. From this perspective, religious heritage sites are containers of not just religious meaning but also broader socio-cultural heritage and spiritual capital, and therefore over time have acquired multiple identities and meanings within society. According to those espousing this view, the methodologies used to interpret sites should include efforts to be as broad, secularized, and globalizing as possible, presenting experiences that are "unintoxicated" by hegemonic religious discourses (Thouki 2018; see also Kaelber 2006; Olsen 2012; Fedele 2013; Curtis 2016). Yet others have argued that there is a need for a greater synthesis of secular heritage and religious theologies behind the creation and structure of these religious sites (Olsen 2012; Thouki 2018, 2019), since many religious site managers use tourism visitation to fulfill both financial and theological goals, and therefore attract visitors with a wide range of motivations and expectations.

In the case of Temple Square, while present site interpretation focuses on an experiential-based platform, where religious iconography and history are intertwined with modern-day applications of religious principles (Olsen 2012), the present plan to make Temple Square more Christ-centered is a move from using Church history to interpret the site to a core theological focus on salvation through Jesus Christ. In doing this, Church leaders hope to use presentations about Jesus Christ as the primary medium through which religious/spiritual experiences are fostered. In the instance of Nauvoo, the decision to rebuild the Nauvoo Temple as a functioning temple rather than a historical replica in essence was a sacralizing one, in that the building of a functioning temple establishes an ideological, physical, and spiritual center for the surrounding Church community (Jackson 1992; Timothy 1992). 
The Nauvoo Temple has only increased the sacred nature of the city for Church members, leading to increased religious tourist visitation to the site. In addition, while the decision to end certain Church pageants may seem antithetical to the move towards making religious sites more religious, at least in the cases of the Hill Cumorah and Manti Mormon Miracle pageants, their cancellation may have been spurred in part by the fact that they were performed in areas at these religious heritage sites that were considered sacred space. In the case of the Hill Cumorah pageant, the staging of the pageant was on the side of the Hill Cumorah, which hill is considered sacred, and in the case of the Manti Mormon Miracle Pageant, the pageant was enacted on temple grounds (Walch 2018). In these instances, it is possible that Church leaders felt that the historical character of these performances outsized the other religious messages of the sites or the faith. ${ }^{5}$

Yet unanswered are how the decisions of Church leaders regarding their religious heritage that have negative economic and socio-cultural impacts can be redressed or remedied by the communities affected by these decisions. In the case of ending Church-sponsored pageants, for example, Church leaders consulted, or at least informed, local ecclesiastical, government, and tourism officials regarding their decision to do away with certain pageants. In these affected communities, it is probably too soon to comment on what the long-term effects of these ecclesiastical decisions may be, including the loss of parts of their socio-cultural identity and what will probably end up being tens of thousands of religious heritage tourism dollars. At the same time, religious leaders have primary control over their religious heritage sites, and as such can make decisions regarding their religious heritage regardless of how external stakeholders feel about those decisions. Religious organizations also do not necessarily have an obligation to reimburse affected destinations for lost tourism revenue or to help them redevelop their socio-cultural identities, although this took place in part in the Nauvoo case study. However, considering the importance of these religious organizations within the broader community, Church leaders can be sensitive to potential economic and socio-cultural losses, explain the rationale for these changes, and give communities time to transition away from the Church's religious heritage as a key component of the heritage tourism economy. Future research therefore might focus on how community leaders have dealt with the aftermath of these changes in the faith's religious heritage from an economic and socio-cultural perspective, as well as how these changes have affected Church-community relations in these communities.

\section{Conclusions}

To diversify offerings and experiences, tourism marketers and promoters in destinations around the world have turned to utilizing the material and immaterial aspects of religious culture and heritage. Like other types of niche tourism markets, religious tourism leads to both positive and negative economic, socio-cultural, and environmental impacts on host destinations, particularly in cases where religious heritage tourism is an important part of a tourist economy. Some of these impacts were outlined in the three case studies discussed in this paper, where the decisions by leaders of The Church of Jesus Christ of Latter-day Saints have led to either potential economic gains or the loss of both economic and socio-cultural stability in several communities in the United States. Changes to the Church's religious heritage were not spurred by concerns regarding the enhancement of the economic and socio-cultural character of the sites in question, but rather based on theological goals related to sacralizing religious heritage sites to enhance expressions of faith. This study highlights the importance of religious institutions and groups as key stakeholders in tourism development and governance that involves religious cultural and heritage sites. Understanding the relationship between the tourism industry and religious institutions, particularly in terms of how religious groups utilize and manage

5 The Mesa Easter Pageant: Jesus the Christ seems to be an exception to this. The continuation of this production, even though it is held on temple grounds, may be due to the content of the pageant itself. The focus of the pageant on the life and teachings of Jesus Christ seems to fit the changing focus of Temple Square to highlight the Church's strong belief in Jesus Christ. 
their sacred sites in order to fulfill their religious or theological goals (Olsen 2011, 2016), can lead to more cooperation and mutual understanding amongst religious managers and outside stakeholders.

Author Contributions: Conceptualization, D.H.O., and S.C.E.; investigation, D.H.O., and S.C.E.; methodology, D.H.O., and S.C.E.; writing—original draft, D.H.O., and S.C.E.; writing—review \& editing, D.H.O., and S.C.E. All authors have read and agreed to the published version of the manuscript.

Funding: This research received no external funding.

Conflicts of Interest: The authors declare no conflict of interest.

\section{References}

Alecu, I. Ciprian. 2010. Epistemological Aspects of Religious Tourism in Rural Areas. International Journal of Business Management and Social Sciences 2: 59-65.

Alton, Jenna. 2019. Extensive Salt Lake Temple Renovations Remaking Temple Square. The Daily Universe. Available online: https:/universe.byu.edu/2019/04/19/salt-lake-temple-closing-for-4-years-for-extensiverenovations-1/ (accessed on 18 September 2019).

Applebome, Peter. 2011. A Mormon Spectacle, Way off Broadway. The New York Times. Available online: https://www.nytimes.com/2011/07/14/nyregion/hill-cumorah-pageant-offers-mormon-spectacleway-off-broadway.html (accessed on 13 September 2016).

Arrington, Leonard J., and David Bitton. 1992. The Mormon Experience: A History of the Latter-Day Saints. Urbana and Chicago: University of Illinois Press.

Ballantyne, Roy, Karen Hughes, and Nigel Bond. 2016. Using a Delphi Approach to Identify Managers' Preferences for Visitor Interpretation at Canterbury Cathedral World Heritage Site. Tourism Management 54: 72-80. [CrossRef]

Bell, James A. 2013. Ritualized theater: The performing pilgrim's process at the Hill Cumorah Pageant. In Mormons and American Popular Culture: The Global Influence of an American Phenomenon. Edited by J. Michael Hunter. Santa Barbara: Praeger, Volume 1, pp. 163-81.

Bennett, Richard E., Susan E. Black, and Donald Q. Cannon. 2010. The Nauvoo Legion in Illinois: A History of the Mormon Militia, 1841-1846. Norman: Arthur H. Clark Company.

Bielo, James S. 2018. Ark Encounter: The Making of a Creationist Theme Park. New York: New York University Press. Branham, Joan R. 2009. The Temple That Won't Quit: Constructing Sacred Space in Orlando's Holy Land Experience Theme Park. Cross Current 59: 358-82. [CrossRef]

Bremer, Thomas S. 2005. Tourism and religion. In Encyclopedia of Religion. Edited by L. Jones. Detroit: Macmillian Reference USA, Thomas Gale, pp. 9260-64.

Bruner, Edward M. 1994. Abraham Lincoln as Authentic Reproduction: A Critique of Postmodernism. American Anthropologist N.S. 96: 397-415. [CrossRef]

Bundt, Michael. 2018. Palmyra Residents Respond to Hill Cumorah Pageant Ending. Rochester First. Available online: https://www.rochesterfirst.com/news/local-news/palmyra-residents-respond-to-hillcumorah-pageant-ending/ (accessed on 18 September 2019).

Bushman, Claudia. 2009. The Pageant People: A Latter-day Saint Appropriation of an Art Form. In Pageants and Processions: Images and Idiom as Spectacle. Edited by Herman du Toit. Tyne: Cambridge Scholars Publishing, pp. 217-24.

Cameron, Catherine M., and John B. Gatewood. 2003. Seeking Numinous Experiences in the Unremembered Past. Ethnology 42: 55-71. [CrossRef]

Cannizzaro, Salvatore, Gian Luigi Corinto, and Enrico Nicosia. 2017. Saint Agatha Religious Festival in Catania: Stakeholders' Functions and Relations. Almatourism: Journal of Tourism, Culture and Territorial Development 8: 124-38.

Carboni, Michele, Carlo Perelli, and Giovanni Sistu. 2014. Is Islamic Tourism a Viable Option for Tunisian Tourism? Insights from Djerba. Tourism Management Perspectives 11: 1-9. [CrossRef]

Cassar, George, and Dane Munro. 2016. Malta: A Differentiated Approach to the Pilgrim-Tourist Dichotomy. International Journal of Religious Tourism and Pilgrimage 4: 67-78.

Casson, Mark, and Catherine Casson. 2014. The History of Entrepreneurship: Medieval Origins of a Modern Phenomenon. Business History 56: 1223-42. [CrossRef] 
Cawthon, Rand. 2000. New Temple Is a Monument to History, Faith, and Hope. Phila: Philadelphia Inquirer, p. A1.

Chmielewska-Szlajfer, Helena. 2017. “Authentic Experience” and Manufactured Entertainment: Holy Land Experience Religious Theme Park. Polish Sociological Review 200: 545-58.

Church Newsroom. 2018. Updated Statement on Local Celebrations, Including Pageants: Three Pageants Will Continue, Four Will End. Available online: https://newsroom.churchofjesuschrist.org/article/statement-localcelebrations-pageants-october-2018 (accessed on 18 September 2019).

City Cooperation to a Necessity. 1962. The Nauvoo Independent, Cited in Journal History of The Church of Jesus Christ of Latter-day Saints, May 10, 1962. Salt Lake City: Church History Library, p. 6.

Cluff, Casey, Brian H. Stone, Kenneth Timothy Sullivan, and Jake Smithwick. 2018. Nauvoo Illinois Historic Site: A Facilities Management Perspective. Journal of Facility Management Education and Research 1: 1-8. [CrossRef]

Cohen, Erik. 1992. Pilgrimage and tourism: Convergence and divergence. In Sacred Journeys: The Anthropology of Pilgrimage. Edited by Alan Morinis. Westport: Greenwood Press, pp. 18-35.

Cohen, Erik. 1998. Tourism and Religion: A Comparative Perspective. Pacific Tourism Review 2: 1-10.

Cohen, Erik. 2018. The Philosophical, Ethical and Theological Groundings of Tourism-An Exploratory Inquiry. Journal of Ecotourism 17: 359-82. [CrossRef]

Cohen, Erik. H. 2006. Religious tourism as an educational experience. In Tourism, Religion and Spiritual Journeys. Edited by Dallen J. Timothy and Daniel H. Olsen. London and New York: Routledge, pp. 94-109.

Coleman, Simon, and John Eade. 2018. Pilgrimage and political economy: Introduction to a research agenda. In Pilgrimage and Political Economy: Translating the Sacred. Edited by S. Coleman and J. Eade. New York: Berghahan Books, pp. 1-20.

Crockett, David, and Lenita Davis. 2016. Commercial Mythmaking at the Holy Land Experience. Consumption Markets $\mathcal{E}$ Culture 19: 206-27.

Curtis, Simon. 2016. English Cathedrals: Events and Spiritual Capital. International Journal of Religious Tourism and Pilgrimage 4: 1-11.

Dahl, Larry E., and Don Norton, eds. 2003. Modern Perspectives on Nauvoo and the Mormons. Provo: Religious Studies Center.

Davis, James A., and Karen Austin. 2002. Nauvoo, Illinois: A Different Kind of Heritage Tourism Site. Tourism Recreation Research 27: 35-40. [CrossRef]

della Dora, Veronica. 2012. Setting and Blurring Boundaries: Pilgrims, Tourists, and Landscape in Mount Athos and Meteora. Annals of Tourism Research 39: 951-74. [CrossRef]

Dennis, Landt. 1975. Old Nauvoo Anew: A Mormon Williamsburg Lives Again in Illinois. Marathon World 3: $14-17$.

Di Giovine, Michael A. 2010. Rethinking Development: Religious Tourism to St. Padre Pio as Material and Cultural Revitalization in Pietrelcina. Tourism 58: 271-78.

Doss, Erika. 2010. Memorial Mania: Public Feeling in America. Chicago: University of Chicago Press.

du Toit, Herman. 2009. Introduction. In Pageants and Processions: Images and Idiom as Spectacle. Edited by Herman du Toit. Tyne: Cambridge Scholars Publishing, pp. xiii-xvi.

Egan, Dan. 2000. Tensions on the Rise Again in Nauvoo. Salt Lake Tribune, January 23, pp. A1, A8.

Egresi, Istvan, Büsra Bayram, Fatih Kara, and Ozan Arif Kesik. 2012. Unlocking the Potential of Religious Tourism in Turkey. GeoJournal of Tourism and Geosites 9: 17-23.

Eid, Riyad. 2012. Towards a High-Quality Religious Tourism Marketing: The Case of Hajj Service in Saudi Arabia. Tourism Analysis 17: 509-22. [CrossRef]

Erekson, Keith A. 2005. From Missionary Resort to Memorial Farm: Commemoration and Capitalism at the Birthplace of Joseph Smith, 1905-1925. Mormon Historical Studies 6: 69-100.

Esplin, Scott C. 2018. Return to the City of Joseph: Modern Mormonism's Contest for the Soul of Nauvoo. Urbana: University of Illinois Press.

Fedele, Anna. 2013. Looking for Mary Magdalene: Alternative Pilgrimage and Ritual Creativity at Catholic Shrines in France. Oxford: Oxford University Press.

Flake, Kathleen. 2003. Re-placing Memory: Latter-day Saint Use of Historical Monuments and Narrative in the Early Twentieth Century. Religion and American Culture: A Journal of Interpretation 13: 69-109. [CrossRef]

Gedecho, Ermias Kifle. 2014. Challenges of Religious Tourism Development: The Case of Gishen Mariam, Ethiopia. American Journal of Tourism Research 3: 42-57. 
Gerlach, Larry R. 2002. Church and Games: The Mormon Church and the Salt Lake City Olympic Winter Games. In The Global Nexus Engaged: Past, Present, Future Interdisciplinary Olympic Studies, Sixth International Symposium for Olympic Research. Edited by Kevin B. Wamsley, Robert K. Bernay and Scott G. Martyn. London: International Centre for Olympic Studies, pp. 13-28.

Gertz, Husar, and Deborah Gertz. 2014. Committee Targets Elementary School Site for Nauvoo Community Center. Quincy Herald-Whig. Available online: https:/www.whig.com/story/26701817/committee-targetselementary-school-site-for-nauvoo-community-center (accessed on 9 October 2019).

Goh, Robbie B. H. 2017. The Jerusalem of Jesus: Space and Pentecostal-Evangelical Branding in Orlando's Holy Land Experience and Eureka Spring's Holy Land Tour. Culture and Religion 18: 296-323. [CrossRef]

Graburn, Nelson H. H. 1989. Tourism: The Sacred Journey. In Hosts and Guests: The Anthropology of Tourism. Edited by Valene L. Smith. Philadelphia: University of Pennsylvania Press, pp. 21-36.

Greif, Avner. 2006. Institutions and the Path to the Modern Economy: Lessons from Medieval Trade. Cambridge: Cambridge University Press.

Gupta, Vasanti. 1999. Sustainable Tourism: Learning from Indian Religious Traditions. International Journal of Contemporary Hospitality Management 11: 91-95. [CrossRef]

Hall, C. Michael. 2006. Travel and journeying on the sea of faith: Perspectives from religious humanism. In Tourism, Religion and Spiritual Journeys. Edited by Dallen J. Timothy and Daniel H. Olsen. London and New York: Routledge, pp. 64-77.

Hamilton, Tom T. 1966. After 120 years old Nauvoo restored. International Harvester Farm Magazine 49: 2-3.

Haq, Farooq. 2013. Islamic Spiritual Tourism: An Innovative Marketing Framework. International Journal of Social Entrepreneurship and Innovation 2: 438-47. [CrossRef]

Hawkins, Donald E., and Maryam M. Khan. 1998. Ecotourism opportunities for developing countries. In Global Tourism. Edited by William F. Theobald. Oxford: Butterworth-Heinemann, pp. 191-204.

Henderson, Joan C. 2011. Religious Tourism and its Management: The Hajj in Saudi Arabia. International Journal of Tourism Research 13: 541-52. [CrossRef]

Heydari Chianeh, Rahim, Giacomo Del Chiappa, and Vahid Ghasemi. 2018. Cultural and Religious Tourism Development in Iran: Prospects and Challenges. Anatolia 29: 204-14. [CrossRef]

Hunter, J. Michael. 2013. Pageants. In Mormons and American Popular Culture: The Global Influence of an American Phenomenon. Edited by J. Michael Hunter. Santa Barbara: Praeger, Volume 2, pp. 166-67.

Huntley, Eritha, and Carol Barnes-Reid. 2003. The Feasibility of Sabbath-Keeping in the Caribbean Hospitality Industry. International Journal of Contemporary Hospitality Management 15: 172-75. [CrossRef]

Ioannides, Mara W. Cohen, and Dimitri Ioannides. 2006. Global Jewish tourism: Pilgrimages and remembrance. In Tourism, Religion and Spiritual Journeys. Edited by Dallen J. Timothy and Daniel H. Olsen. London and New York: Routledge, pp. 156-71.

Jackson, Richard H. 1992. Historical sites. In Encyclopedia of Mormonism. Edited by Daniel H. Ludlow. New York: Macmillan Publishing, pp. 592-95.

Jackson, Richard H., and Roger Henrie. 1983. Perception of Sacred Space. Journal of Cultural Geography 3: 94-107. [CrossRef]

Jones, Megan Sanborn. 2018. Contemporary Mormon Pageantry: Seeking after the Dead. Ann Arbor: University of Michigan Press.

Kaelber, Lutz. 2006. Paradigms of travel: From medieval pilgrimage to the postmodern virtual tour. In Tourism, Religion and Spiritual Journeys. Edited by D. J. Timothy and D. H. Olsen. London and New York: Routledge, pp. 49-63.

Kartal, Burak, Mustafa Tepeci, and Hakan Atli. 2015. Examining the Religious Tourism Potential of Manisa, Turkey with a Marketing Perspective. Tourism Review 70: 214-31. [CrossRef]

Kaylor, Brian T. 2009. The Holy Land Experience: Proposing a typology for studying museum communication. Florida Communication Journal 37: 11-22.

Kelly, John Robert. 1982. Leisure. Englewood Cliffs: Prentice Hall, Inc.

Kelner, Shaul. 2012. Tours that Bind: Diaspora, Pilgrimage, and Israeli Birthright Tourism. New York: New York University Press.

Khaksari, Ali, Timothy Jeonglyeol Lee, and Choong-Ki Lee. 2014. Religious Perceptions and Hegemony on Tourism Development: The case of the Islamic Republic of Iran. International Journal of Tourism Research 16: 97-103. [CrossRef] 
KHQA Newsdesk. 2013. Nauvoo LDS Church Sends Rebate Checks to Residents. KHQA.com. Available online: https://khqa.com/news/local/nauvoo-lds-church-sends-rebate-checks-to-residents (accessed on 28 February 2020).

King, Seth S. 1970a. Mormons restore Illinois village. New York Times, September 9, pp. 49, 55.

King, Seth. 1970b. Mormons restore old homestead. The Kansas City Times, September 17, p. 8A.

Kinzer, Stephen. 2004. Mormon renewal creates a stir in an Illinois town. New York Times, July 29, p. 12A.

Kirillova, Ksenia, Alsu Gilmetdinova, and Xiran Lehto. 2014. Interpretation of Hospitality across Religions. International Journal of Hospitality Management 43: 23-34. [CrossRef]

Kitiarsa, Pattana. 2008. Religious Commodifications in Asia: Marketing Gods. London and New York: Routledge.

Kitiarsa, Pattana. 2010. Toward a sociology of religious commodification. In The New Blackwell Companion to the Sociology of Religion. Edited by Brian S. Turner. Malden: Blackwell, pp. 563-79.

Klein, Jerry. 1979. Nauvoo, the Town the Mormons Left. New York Times, August 19. Available online: https://www.nytimes.com/1979/08/19/archives/nauvoo-the-town-the-mormons-left-the-town-themormons-fled.html (accessed on 21 February 2020).

Koskansky, Oren. 2002. Tourism, Charity, and Profit: The Movement of Money in Moroccan Jewish Pilgrimage. Cultural Anthropology 17: 359-400. [CrossRef]

KSL TV. 2019. Salt Lake Temple Will Close for 4-Year Renovation Project. Available online: https://ksltv.com/ 412188/church-temple-square-renovations/ (accessed on 18 September 2019).

Labadi, Sophia. 2010. World Heritage, authenticity and post-authenticity: International and national perspectives. In Heritage and Globalisation. Edited by Sophia Labadi and Colin Long. London and New York: Routledge, pp. 66-84.

Leonard, Glen M. 2002. Nauvoo: A Place of Peace, a People of Promise. Salt Lake City: Deseret Book.

Lloyd, David W. 1998. Battlefield Tourism. New York: Berg.

Lonsberry, Amanda. 2018. Hill Cumorah Pageant to End in 2020. Hill Cumorah. Available online: https: //www.hillcumorah.org/?p=700 (accessed on 18 September 2019).

Lunt, David J. 2007. Mormons and the Olympics: Constructing an Olympic Identity. Olympika: The International Journal of Olympic Studies 16: 1-18.

MacCannell, Dean. 1976. The Tourist: A New Theory of the Leisure Class. New York: Schocken.

MacKay, Michael Hubbard. 2016. Sacred Space: Exploring the Birthplace of Mormonism. Provo: Religious Studies Center.

Madsen, Michael H. 2006. The Sanctification of Mormonism's Historical Geography. Journal of Mormon History 34: 228-55.

Martin, Stephen A. 1999. Nauvoo clears way for LDS temple. Deseret News, October 20, pp. A1, A6.

Martin, Stephen A. 2000a. Nauvoo temple construction building hopes of prosperity. Deseret News, February 14, pp. D8, D10.

Martin, Stephen A. 2000b. Time magazine does Nauvoo: Media on 2-week river trip down the Mississippi. Deseret News, April 25, pp. B1-2.

Martin, Stephen A. 2001. Nauvoo firehouse gets a vertical lift. The Burlington Hawk Eye, November 11.

Marty, M. E. 1981. Foreword. In Mormonism and the American Experience. Edited by Klaus J. Hansen. Chicago: University of Chicago Press.

Mathews, Jana. 2015. Theme Park Bibles: Trinity Broadcasting Network's Holy Land Experience and the Evangelical Use of the Documentary Past. The Journal of Religion and Popular Culture 27: 89-104. [CrossRef]

Mattila, Anna S., Yorghos Apostolopoulos, Sevil Sonmez, Lucy Yu, and Vinod Sasidharan. 2001. The Impact of Gender and Religion on College Students' Spring Break. Journal of Travel Research 40: 193-200. [CrossRef]

McKelvie, Jenny. 2005. Religious Tourism. Travel E Tourism Analyst 4: 1-47.

Metreveli, Mariana, and Dallen J. Timothy. 2010. Religious Heritage and Emerging Tourism in the Republic of Georgia. Journal of Heritage Tourism 5: 237-44. [CrossRef]

Millman, Roger. 1988. Just Pleasure: The Churches Look at Tourism's Impacts. Annals of Tourism Research 15: 555-58. [CrossRef]

Moal-Ulvoas, Gaëlle. M. 2016. The Tourism Experience Offered by Religious Theme Parks: Taman Tamadun Islam (TTI) in Malaysia. International Journal of Religious Tourism and Pilgrimage 4: 59-66.

Monk, Charlene Faye. 1998. Passion Plays in the United States: The Contemporary Outdoor Tradition. Ph.D. Thesis, Louisiana State University, Baton Rouge, LA, USA. 
Moore, Carrie A. 2002. Nauvoo Temple-A Vision of the Past. Deseret News. Available online: https: //www.deseret.com/2002/5/16/19781492/nauvoo-temple-151-a-vision-of-the-past (accessed on 9 October 2019).

Nauvoo Community Center Project History. 2019. Available online: https://www.nauvoocommunitycenter.org/ project-history (accessed on 9 October 2019).

Nauvoo Restoration. 1962. Nauvoo to Have Noted Visitors. Nauvoo Restoration Incorporated Corporate Files. Nauvoo: Nauvoo Restoration, May 18.

Nielsen, Liesl. 2019. Here's What Will Happen during the 4-Year Closure of the Salt Lake Temple. KSL.com. Available online: https:/www.ksl.com/article/46685668/heres-what-will-happen-during-the-4-year-closureof-the-salt-lake-temple (accessed on 15 December 2019).

O'Guinn, Thomas C., and Russell W. Belk. 1989. Heaven on Earth: Consumption at Heritage Village, USA. Journal of Consumer Research 16: 227-38.

Okonkwo, Emeka. 2015. Religious Activities and their Tourism Potential in Sukur Kingdom, Nigeria. International Journal of Religious Tourism and Pilgrimage 3: 1-11.

Olsen, Daniel H. 2003. Heritage, tourism, and the commodification of religion. Tourism Recreation Research 28: 99-104. [CrossRef]

Olsen, Daniel H. 2006. Management issues for religious heritage attractions. In Tourism, Religion and Spirituality. Edited by Dallen J. Timothy and Daniel H. Olsen. London and New York: Routledge, pp. 104-18.

Olsen, Daniel H. 2009. "The Strangers within Our Gates": Managing visitors at Temple Square. Journal of Management, Spirituality \& Religion 6: 121-39.

Olsen, Daniel H. 2011. Towards a religious view of tourism: Negotiating faith perspectives on tourism. Journal of Tourism, Culture and Communication 11: 17-30. [CrossRef]

Olsen, Daniel H. 2012. Teaching Truth in "Third Space": The Use of Religious History as a Pedagogical Instrument at Temple Square in Salt Lake City, Utah. Tourism Recreation Research 37: 227-37. [CrossRef]

Olsen, Daniel H. 2013. Touring sacred history: The Latter-day Saints and their historical sites. In Mormons and American Popular Culture: The Global Influence of an American Phenomenon. Edited by J. Michael Hunter. Santa Barbara: Praeger, volume 2, pp. 225-42.

Olsen, Daniel H. 2016. The Church of Jesus Christ of Latter-day Saints, Their “Three-Fold Mission," and Practical and Pastoral Theology. Practical Matters: A Journal of Religious Practices and Practical Theology 9: 27-51.

Olsen, Daniel H. 2019. Best Practice and Sacred Site Management: The Case of Temple Square in Salt Lake City, Utah. In Managing Religious Tourism. Edited by Maureen Griffins and Peter Wiltshier. Oxfordshire: CABI, pp. 65-78.

Olsen, Daniel H., and Brian Hill. 2018. Pilgrimage and identity along the Mormon Trail. In Religious Pilgrimage Routes and Trails: Sustainable Development and Management. Edited by Daniel H. Olsen and Anna Trono. Oxfordshire: CABI, pp. 224-46.

Olsen, Daniel H., and Dallen J. Timothy. 2002. Contested Religious Heritage: Differing Views of Mormon Heritage. Tourism Recreation Research 27: 7-15. [CrossRef]

Olsen, Daniel H., and Dallen J. Timothy. 2018. Tourism, Salt Lake City, and the cultural heritage of Mormonism. In Tourism and Religion: Issues, Trends and Implications. Edited by Richard Butler and Wantanee Suntikul. Bristol: Channel View Publications, pp. 250-69.

Olsen, Daniel H., and Dallen J. Timothy. Forthcoming. Contemporary Perspectives of Pilgrimage. In Pilgrims: Values and Identities. Edited by Darius Liutikas. Oxfordshire: CABI.

Olsen, Daniel H., Anna Trono, and Paul Fidgeon. 2018. Pilgrimage Trails and Routes: Journeys from the Past to the Present. In Religious Pilgrimage Routes and Trails: Sustainable Development and Management. Edited by Daniel H. Olsen and Anna Trono. Oxfordshire: CABI, pp. 1-13.

Ornella, Alexander Darius. 2013. Commodification of Religion. In Encyclopedia of Sciences and Religions. Edited by Anne L. C. Runehov and L. Oviedo. Dordrecht: Springer, pp. 430-31.

Packer, Boyd K. 1980. The Holy Temple. Salt Lake City: Bookcraft.

Paine, Crispin. 2019. Gods and Rollercoasters: Religion in Theme Parks Worldwide. London: Bloomsbury Academic. Park, Chris C. 1994. Sacred Worlds: An Introduction to Geography and Religion. London: Routledge.

Parker, Alexander A. 1935. Notes on the Religious Drama in Mediæval Spain and the Origins of the "Auto Sacramental". The Modern Language Review 30: 170-82. [CrossRef] 
Pavicic, Jurica, Nikisa Alfirevic, and Vincent John Batarelo. 2007. The management and marketing of religious sites, pilgrimage and religious events: Challenges for Roman Catholic pilgrimages in Croatia. In Religious Tourism and Pilgrimage Management: An International Perspective. Edited by Razaq Raj and Nigel D. Morpeth. Oxfordshire: CABI, pp. 48-63.

Poria, Yaniv, Arie Reichel, and Raviv Cohen. 2011. World Heritage Site-Is it an Effective Brand Name? A Case Study of a Religious Heritage Site. Journal of Travel Research 50: 482-95. [CrossRef]

Porok, Carolyn V. 2003. Transplanting Pilgrimage Traditions in the Americas. Geographical Review 93: $283-7$. [CrossRef]

Preston, James J. 1992. Spiritual Magnetism: An Organizing Principle for the Study of Pilgrimage. In Sacred Journeys: The Anthropology of Pilgrimage. Edited by Alan Morinis. Westport: Greenwood Press, pp. 31-46.

Pugmire, Genelle. 2019. LDS Church to Close Salt Lake Temple for 4-Year Renovation. Herald Extra. Available online: https:/www.heraldextra.com/news/local/faith/lds-church-to-close-salt-lake-temple-for-year/article_f6f8c129-577c-5b37-b0ae-6ad6e235ba3c.html (accessed on 23 September 2019).

Pykles, Benjamin C. 2010. Excavating Nauvoo: The Mormons and the Rise of Historical Archaeology in America. Lincoln: University of Nebraska Press.

Qurashi, Jahanzeeb. 2017. Commodification of Islamic Religious Tourism: From Spiritual to Touristic Experience. International Journal of Religious Tourism and Pilgrimage 5: 89-104.

Rebuilding at Nauvoo. 1970. St. Louis Post-Dispatch, December 13.

Riess, Jana. 2019. A Swan Song for Mormons' Hill Cumorah Pageant. Salt Lake Tribune. Available online: https://www.sltrib.com/religion/local/2019/07/16/jana-riess-swan-song/ (accessed on 11 October 2019).

Rountree, Kathryn. 2002. Goddess Pilgrims as Tourists: Inscribing the Body through Sacred Travel. Sociology of Religion 63: 475-96. [CrossRef]

Rountree, Kathryn. 2006. Performing the Divine: Neo-Pagan Pilgrimages and Embodiment at Sacred Sites. Body E Society 12: 95-115.

Rountree, Kathryn. 2010. Tourist attractions, cultural icons, sites of sacred encounter: Engagements with Malta's Neolithic temples. In Thinking through Tourism. Edited by Julie Scott and Tom Selwyn. New York: Berg, pp. 183-208.

Rowan, Yorke. 2004. Repackaging the Pilgrimage: Visiting the Holy Land in Orlando. In Marketing Heritage: Archaeology and the Consumption of the Past. Edited by Yorke Rowan and Uzi Baram. Walnut Creek: AltaMira Press, pp. 249-66.

Rugh, Susan S. 2008. Are We There Yet? The Golden Age of American Family Vacations. Lawrence: University Press of Kansas.

Saal, Mark. 2019. Mormon Miracle Pageant Prepares to Take Final Bows in Manti. Herald Extra. Available online: https://www.heraldextra.com/entertainment/arts-and-theater/mormon-miracle-pageantprepares-to-take-final-bows-in-manti/article_4ed12755-662b-5010-96e2-44b2cb2661ab.html (accessed on 19 September 2019).

Shackley, Myra. 1999. Managing the cultural impacts of religious tourism in the Himalayas, Tibet and Nepal. In Tourism \& Cultural Conflicts. Edited by Mike Robinson and Priscilla Boniface. New York: CABI Publishing, pp. 95-111.

Shackley, Myra. 2001. Managing Sacred Sites: Service Provision and Visitor Experience. London and New York: Continuum.

Shackley, Myra. 2003. Management challenges for religion-based attractions. In Managing Visitor Attractions: New Directions. Edited by Alan Fyall, Brian Garrod and Anna Leask. Oxford: Butterworth-Heinemann, pp. 159-70.

Shepherd, Robert J. 2013. Faith in Heritage: Displacement, Development, and Religious Tourism in Contemporary China. Walnut Creek: Left Coast Press.

Shinde, Kiran A. 2011. What are Charitable Trusts doing in Religious Tourism? Insights from an Indian Pilgrimage Site. Tourism Planning \& Development 8: 21-36.

Shinde, Kiran A. 2012. Policy, Planning, and Management for Religious Tourism in Indian Pilgrimage Sites. Journal of Policy Research in Tourism, Leisure and Events 4: 277-301. [CrossRef]

Shinde, Kiran A. 2018. Augmenting pilgrimages: A religious theme park in Shegaon, Maharashtra. In Religious Journeys in India: Pilgrims, Tourists, and Travelers. Edited by Andrea Marion Pinkney and John Whalen-Bridge. Albany: University of New York Press, pp. 65-90. 
Shumway, J. Matthew. 2015. Tithes, Offerings and Sugar Beets: The Economic Logistics of the Church of Jesus Christ of Latter-Day Saints. In The Changing World Region Map. Edited by Stanley D. Brunn. Dordrecht: Springer, pp. 1207-228.

Simone-Charteris, Maria Teresa, and Stephen W. Boyd. 2011. The Potential for Northern Ireland to Promote Politico-Religious Tourism: An Industry Perspective. Journal of Hospitality Marketing \& Management 20: 457-83.

Singh, Shalini. 2006. Tourism in the Sacred Indian Himalayas: An Incipient Theology of Tourism? Asia Pacific Journal of Tourism Research 11: 375-89. [CrossRef]

Smiraglia, Christina. 2013. The Gazophylacium: An Argument for European Medieval Religious Sites as the First Museums in the West. Museum History Journal 6: 237-52. [CrossRef]

Smith, Laurajane. 2006. Uses of Heritage. Oxford: Routledge.

Sprigg, June. 1980. Out of This World: The Shakers as a 19th-Century Tourist Attraction. American Heritage 31: 65-68.

Srisang, Koson. 1989. The Ecumenical Coalition on Third World Tourism. Annals of Tourism Research 16: 119-25. [CrossRef]

Stack, Peggy Fletcher. 2018a. For Manti's Mormon Miracle Pageant, It Turns out the Show Won't Go on after Next Year. Salt Lake Tribune. Available online: https://www.sltrib.com/religion/2018/12/04/mantis-mormonmiracle/ (accessed on 18 September 2019).

Stack, Peggy Fletcher. 2018b. For the First Time in Its 80-Year History, Hill Cumorah Pageant Will Be off-Limits to-Who Would Have Guessed?-Full-Time Mormon Missionaries. Salt Lake Tribune. Available online: https:/www.sltrib.com/news/nation-world/2018/07/20/first-time-its-year/ (accessed on 18 September 2019).

Stausberg, Michael. 2011. Religion and Tourism: Crossroads, Destinations, and Encounters. London: Routledge.

Stevens, T. 1988. The Ministry of Welcome: Tourism and Religious Sites. Leisure Management 8: 41-44.

Sumption, Jonathan. 2003. The Age of Pilgrimage: The Medieval Journey to God. Mahwah: Hidden Spring.

Suntikul, Wantanee, and Richard W. Butler, eds. 2018. Tourism and Religion: Origins, Interactions and Issues. In Tourism and Religion: Issues and Implications. Bristol: Channel View, pp. 1-9.

Terzidou, Matina, Dimitrios Stylidis, and Edith M. Szivas. 2008. Residents' Perceptions of Religious Tourism and its Socio-Economic Impacts on the Island of Tinos. Tourism and Hospitality Planning E Development 5: 113-29.

Terzidou, Matina, Dimitrios Stylidis, and Konstantinos Terzidis. 2018. The Role of Visual Media in Religious Tourists' Destination Image, Choice, and On-Site Experience: The Case of Tinos, Greece. Journal of Travel $\mathcal{E}$ Tourism Marketing 35: 306-19.

Thouki, Alexis. 2018. Interpretation of sacred sites: Methodological challenges in balancing materiality and spirituality. Paper presented at Heritage 2018: Proceedings of the 6th International Conference on Heritage and Sustainable Development, Granada, Spain, 12-15 June 2018; Edited by Rogério Amoêda, Sérgio Kira, Cristina Pinheiro, Juan M. Santiago Zaragoza, Julio Calvo Serrano and Fabián García Carillo. Granada: Editorial Universidad de Granda, Volume 2, pp. 2093-102.

Thouki, Alexis. 2019. The Role of Ontology in Religious Tourism Education-Exploring the Application of the Postmodern Cultural Paradigm in European Religious Sites. Religions 10: 649. [CrossRef]

Tilson, Doon James. 2001. Religious Tourism, Public Relations and Church-State Partnerships. Public Relations Quarterly 46: 35-39.

Tilson, Dallen J. 2005. Religious-Spiritual Tourism and Promotional Campaigning: A Church-state Partnership for St. James and Spain. Journal of Hospitality E Leisure Marketing 12: 9-40.

Timothy, Dallen J. 1992. Mormons in Ontario: Early History, Growth and Landscape. Ontario Geography 38: 21-31.

Timothy, Dallen J. 2011. Cultural and Heritage Tourism: An Introduction. Bristol: Channel View Publications.

Timothy, Dallen J., and Daniel H. Olsen. 2006. Conclusion: Whither religious tourism? In Tourism, Religion and Spiritual Journeys. Edited by Dallen J. Timothy and Daniel H. Olsen. London and New York: Routledge, pp. 271-78.

Timothy, Dallen J., and Daniel H. Olsen. 2018. Religious routes, pilgrim trails: Spiritual pathways as tourism resources. In Tourism and Religion: Issues, Trends and Implications. Edited by Richard Butler and Wantanee Suntikul. Bristol: Channel View Publications, pp. 220-35.

Timothy, Dallen J., and Amos Ron. 2019. Christian tourism in the Middle East: Holy Land and Mediterranean perspectives. In Routledge Handbook on Tourism in the Middle East and North Africa. Edited by Dallen J. Timothy. London and New York: Routledge, pp. 147-59. 
Tobler, Douglas F., and S. George Ellsworth. 1992. History, significance to Latter-day Saints. In Encyclopedia of Mormonism. Edited by Daniel H. Ludlow. New York: Macmillan Publishing, pp. 595-98.

Toone, Trent. 2019. Manti's Mormon Miracle Pageant Prepares to come to a Close with 52 Years of Memories. Deseret News. Available online: https://www.deseret.com/2019/6/13/20675877/manti-s-mormon-miraclepageant-prepares-to-come-to-a-close-with-52-years-of-memories\#dane-woods-eli-christensen-andkarson-ward-talk-while-playing-a-game-on-a-phone-prior-to-a-performance-of-the-mormon-miraclepageant-on-wednesday-june-12-2019-in-manti-utah (accessed on 11 October 2019).

Turner, John. 2018. Mormon Pageants, Past, Present, and Future. Anxious Bench. Available online: https: //www.patheos.com/blogs/anxiousbench/2018/11/mormon-pageants-past-present-and-future/ (accessed on 18 September 2019).

Uriely, Natan, Aviad Israeli, and Arie Reichel. 2003. Religious Identity and Residents' Attitudes toward Heritage Tourism Development: The case of Nazareth. Journal of Hospitality $\mathcal{E}$ Tourism Research 27: 69-84.

Van Biema, David, and J. Grace. 2000. The Invasion of the Latter-day Saints. Time Magazine 156: 64-65.

Walch, Tad. 2018. Church Finalizes Pageant Decision: 4 to End, 3 to Continue. Deseret News. Available online: https://www.deseret.com/2018/12/5/20660498/church-finalizes-pageant-decision-4-to-end-3-to-continue\# an-undated-photo-from-the-mormon-miracle-pageant-in-manti-the-church-announced-the-pageantwill-be-discontinued-after-2019 (accessed on 18 September 2019).

Walch, Tad. 2019. Salt Lake Temple to Close for Four Years as Temple Square Undergoes Seismic Change. Deseret News. Available online: https://www.deseret.com/2019/4/19/20671430/salt-lake-temple-to-close-for-fouryears-as-temple-square-undergoes-seismic-change\#president-russell-m-nelson-of-the-church-of-jesuschrist-of-latter-day-saints-shakes-hands-with-dignitaries-prior-to-speaking-during-a-press-conferencein-salt-lake-city-on-friday-april-19-2019-about-renovation-plans-for-the-salt-lake-temple-and-historictemple-square (accessed on 19 September 2019).

Weaver, Jennifer, and Ginna Roe. 2018. LDS Church Issues Its Decisions on Pageants, Ending 4 while Keeping 3 Productions. KUTV.com. Available online: https://kutv.com/news/local/lds-church-issues-its-decisions-onpageant-products-ending-4-while-keeping-3-productions (accessed on 19 August 2019).

West, Camille. 2018. Church Statement "Discourages" Large Pageants. Church Newsroom. Available online: https://www.churchofjesuschrist.org/church/news/church-statement-discourages-large-pageants? lang=eng (accessed on 18 September 2019).

Wiltshier, Peter, and Alan Clarke. 2012. Tourism to Religious Sites, Case Studies from Hungary and England: Exploring Paradoxical Views on Tourism, Commodification and Cost-Benefits. International Journal of Tourism Policy 4: 132-45. [CrossRef]

Wiltshier, Peter, and Maureen Griffiths. 2016. Management Practices for the Development of Religious Tourism Sacred Sites: Managing expectations through sacred and secular aims in site development; report, store and access. International Journal of Religious Tourism and Pilgrimage 4: 1-8.

Woodward, S. C. 2004. Faith and Tourism: Planning Tourism in Relation to Places of Worship. Tourism and Hospitality Planning \& Development 1: 173-86.

World Tourism Organization. 2011. Religious Tourism in Asia and the Pacific. Madrid: World Tourism Organization.

Zamani-Farahani, Hamira, and Joan C. Henderson. 2010. Islamic Tourism and Managing Tourism Development in Islamic Societies: The Cases of Iran and Saudi Arabia. International Journal of Tourism Research 12: 79-89. [CrossRef]

Zwissler, Laurel. 2011. Pagan Pilgrimage: New Religious Movements Research on Sacred Travel within Pagan and New Age Communities. Religion Compass 5: 326-42. [CrossRef]

(C) 2020 by the authors. Licensee MDPI, Basel, Switzerland. This article is an open access article distributed under the terms and conditions of the Creative Commons Attribution (CC BY) license (http://creativecommons.org/licenses/by/4.0/). 